\title{
Utilizing Bacteria to Mitigate Global Climate Change: A Review
}

\author{
Shaurya Dumka, Chinmay Gupta and Aman Kamboj* \\ College of Veterinary and Animal Sciences, G.B. Pant University of Agriculture and \\ Technology, Pantnagar, Udham Singh Nagar- 263145, Uttarakhand, India \\ *Corresponding author
}

K e y w o r d s
$\begin{aligned} & \text { Utilizing bacteria, } \\ & \text { Global climate } \\ & \text { change, Green } \\ & \text { house }\end{aligned}$
Article Info
$\begin{aligned} & \text { Accepted: } \\ & 10 \text { April } 2020 \\ & \text { Available Online: } \\ & 10 \text { May } 2020\end{aligned}$

\section{A B S T R A C T}

At present, the global climate change is one of the biggest challenges in front of human race which results mainly from global warming due to an increased concentration of green house gases in the atmosphere. Among the major green house gases, Carbon dioxide and methane contribute maximum toward the global warming. To mitigate the global climate change the reduction in emission of green house gases is necessary. Microorganisms play a crucial role in the regulation and utilization of these gases. Bacteria can be employed in various ways to address the problem of global climate change through utilization of atmospheric green house gases. This article will present a comprehensive review of the approaches that can present better solutions to reduce the atmospheric green house gases, mainly, CO2 and methane by using bacteria. Recent advances in biofuel research, nanodevices and creation of engineered carbon eating bacteria are some of the novel approaches which can open the new doors to mitigate global climate change.

\section{Introduction}

The global climate change is one of the most debated topics over the last few decades from both scientific and political point of view. Global warming is considered as one of the most significant factor leading to climate change. Global warming refers to an increase in average temperature of earth's surface due to an increased concentration of green house gases (GHGs) in the atmosphere
(Venkataramanan, 2011). Green house effect is the heat retention mechanism facilitated by the GHGs which make earth suitable for the survival of living beings. But the gradual increase in the concentration of GHGs leads to an increase in average surface temperature of earth which results in the global climate change (Anderson et al., 2016). Naturally, GHGs are present in the atmosphere in small quantities. Carbon dioxide $\left(\mathrm{CO}_{2}\right)$, methane $\left(\mathrm{CH}_{4}\right)$, nitrous oxide $\left(\mathrm{N}_{2} \mathrm{O}\right)$ and ozone $\left(\mathrm{O}_{3}\right)$ 
are the major GHGs present in atmosphere. Out of these GHGs, $\mathrm{CO}_{2}$ has been recognized to play most significant role in global warming (Al-Ghussain, 2018). There are broadly two causes of increasing GHGs in the atmosphere: Natural and Anthropogenic causes. Natural causes like volcanic eruptions, oceanic release, respiration, and decomposition causes slow impact on the climate change as compared to anthropogenic causes. Anthropogenic causes, also known as man-made causes are those which involve the human activities leading to release of GHGs into the atmosphere (Kumar et al., 2012). If we look the contribution of various GHGs in global warming, as per United States Environmental protection agency, $\mathrm{CO}_{2}$ accounts for $81.6 \%$ of all $\mathrm{U} \mathrm{S}$ green house gases emissions from human activities followed by methane $(10.2 \%)$, nitrous oxide $(5.6 \%)$ and fluorinated gases $(<2.6 \%)$ in year 2017. Among the sources of $\mathrm{CO}_{2}$ emission transportation contributes maximum (34\%) to $\mathrm{CO}_{2}$ emission followed by electricity (33\%) and industry (15\%) (EPA, 2017). The emission of methane is largely contributed by natural gas and petroleum industry $(31 \%)$ and enteric fermentation (27\%) by domestic livestock like cattle, swine, sheep, and goats as a part of their normal digestive process (EPA, 2017). It has been observed that there is a significant increase in $\mathrm{CO} 2$ concentration by about $30 \%$ since 1950 (Al-Ghussain, 2018). If we look upon our country, in year 2010, India ranked as the third largest GHG emitter and responsible for $5 \%$ of total world $\mathrm{CO}_{2}$ emissions (Chaturvedi et al., 2014; Nejat et al., 2015). According to National Oceanic and Atmospheric Administration (NOAA), USA, global climate summary, 2019, the combined land and ocean temperature has witnessed an average increase of $0.07^{\circ} \mathrm{C}$ $\left(0.13^{\circ} \mathrm{F}\right)$ per decade since 1880 . However the average increase after 1881 is $0.18^{\circ} \mathrm{C}\left(0.32^{\circ} \mathrm{F}\right)$ which is more than twice as great (NOAA, 2019). It is, therefore, important to employ the mitigation strategies which either reduce the emission or utilize the atmospheric GHGs. The first strategy employs the smart ways of energy and waste management, increasing forest cover, adoption of climate smart agriculture and use of green buildings etc. Over the last few decades several strategies has been devised to reduce atmospheric $\mathrm{CO}_{2}$ emission and synthetic biology is one of them which renders the synthetic life forms to convert $\mathrm{CO}_{2}$ into fuel, food and useful organic compounds. Among the biological ways of GHG mitigation bacteria are on the forefront. Recent, it has been found that bacteria can be engineered in a manner to generate biomass from the consumed atmospheric $\mathrm{CO}_{2}$. Some bacteria have their natural capabilities to utilize the gases like methane.

\section{Microbial metabolism and $\mathrm{CO}_{2}$ utilization}

The microbial metabolism plays a critical role in the development and maintenance of earth's biosphere. Unlike eukaryotic organisms, prokaryotes can metabolize a wide range of organic and inorganic matter ranging from complex organic substances like cellulose to inorganic ions like atmospheric gases and metal ions (Oren, 2010). Microbes utilize these substrates to form the useful metabolic products and biomass production. This metabolic diversity of microbes makes them a potential candidate for the reduction of substances which contribute to global warming especially $\mathrm{CO}_{2}$ and methane. Prokaryotic microorganisms are the main players of biochemical transformation of carbon, nitrogen, sulfur, iron, and other elements (Lamers et al., 2012). Due to this reason they are extensively used in environmental engineering like in the process of reducing environmental pollution known as bioremediation and water purification (Abatenh et al., 2017). Based on the source of carbon for metabolism microbes can be divided into autotrophs and heterotrophs. 
Autotrophs utilize $\mathrm{CO}_{2}$ as a principal carbon source and form their own food whereas the heterotrophs are those organisms which depend on the preformed carbon sources or on other organisms for their food (Hunt et al., 2018). The autotrophs can be further divided into photoautotrophs (photosynthetic) which make use of light energy and chemoautotrophs (chemosynthetic) which utilize chemical energy. In autotrophs most of $\mathrm{CO}_{2}$ is assimilated through Calvin cycle, with ribulose bisphosphate carboxylase (RuBisCO) as main enzyme (Berg et al., 2002). However, heterotrophic bacteria are more abundant in nature but we are more concerned to autotrophic bacteria because they have the more significant role to play in the reduction of green house gases. The autotrophic bacteria can be effectively utilized for the bioconversion of $\mathrm{CO}_{2}$ into the desired product with higher selectivity.

\section{Methanogenic Bacteria and GHG sequestration}

Methane is another most important GHG responsible for global warming. Methane has relatively shorter atmospheric lifetime or short lived than $\mathrm{CO}_{2}$ but it has a higher global warming potential than $\mathrm{CO}_{2}$ as it can absorb more energy than $\mathrm{CO}_{2}$ (Al-Ghussain, 2018). Methane is produced by the decay of organic matter under anaerobic condition. The major natural sources of methane include wetlands, oceans, paddy cultivation and livestock. Among these sources, enteric fermentation in the ruminants contributes around $17 \%$ of the global methane production (Knapp et al., 2014). This fermentation is carried out by methanogenic microbes present in the ruminal compartment of Ruminant animals which includes bacteria (archaea), protozoa and fungi. The unique environment of rumen and lower segment of intestine i.e. rapid passage rate, readily available $\mathrm{CO}_{2}$ and hydrogen $\left(\mathrm{H}_{2}\right)$ help the colonization of certain archaea.
These archaea are different from other anaerobic bacteria in their ability to scavenge $\mathrm{CO}_{2}$ and $\mathrm{H}_{2}$ generated by the fermentation process to produce methane (Martin et al., 2010). The other substrates for methanogens include formic acid and methyl amines produced by other ruminal microbes. The common rumen methanogenic species includes Methanobacterium formicicum, Methanobacterium bryantii, Methanobrevibacter ruminantium, Methanobrevibacter millerae, Methanobrevibacter olleyae, Methanomicrobium mobile, Methanoculleus olentangyi and Methanosarcina barkeri (Janssen and Kirs, 2008). These methanogenic organisms produce methane by utilizing $\mathrm{CO}_{2}$ and hydrogen. The production of methane from ruminants and its impact on global climate change is gaining the concern day by day. Methane also serves as a major source of energy loss in animals and account for about 2-12\% loss of gross energy intake (Johnson and Johnson, 1995). So it is desirable to decrease the methane production by livestock without altering animal production to reduce GHG emission and improving feed conversion efficiency of animals as well. There are various strategies or biotechnologies which can be employed to reduce the ruminal methane production targeting ruminal microflora mainly methanogenic bacteria. These techniques includes immunization or biological control of ruminal methanogens, use of probiotics, removal of protozoa or defaunation, mitigation through feed additives, feeding management and genetic manipulations of ruminal microbes for reduced methane production (Martin et al., 2010; Wright et al., 2004; Morgavi et al., 2008). There are certain genes identified in rumen methanogenic bacteria which are involved in the process of methanogenesis viz. mtr, mta, mcr, hmd and fno (Patra et al., 2017) The variation in expression of these genes alters the ruminal 
ability to produce methane. Certain substances like rice straw extract has been shown to alter the expression level of genes involved in the process of methanogenesis (Faseleh et al., 2013). Another livestock derived source of methane is the ruminant excreta e.g. Cow dung which can be effectively converted to biogas that primarily consist of methane and $\mathrm{CO}_{2}$. It does not pose severe threat to the climate change as it is consumed as fuel for the household and other purposes. Apart from animal sources, the other sources like wetlands, oceans, rice fields and landfills cause a huge and serious atmospheric emission of methane produced by methanogens which are not much characterized yet (Pandey et al., 2015). So, it is clear that identification, characterization and manipulation of methanogens using biotechnological approaches is necessary to reduce the atmospheric emission of methane.

\section{Role of Soil and Ocean microbes in} reducing GHGs emission

Soil microbes play a crucial role to establish ecological equilibrium that sustains the life processes. The important roles that soil microflora play includes decomposition of organic matter, recycling of nutrients, production of trace gases and biotransformation of metals and elements (Gupta et al., 2014). Through these processes soil microbes play a vital role in the production and consumption of GHGs. To utilize the soil microbes in mitigation of $\mathrm{GHG}$ production, it is prerequisite to understand their role as contributors and as reactive components of global climate change. The gases produced by human activities can be effectively utilized by soil microbes and neutralize their effect on climate change. Soil serves as a good habitat of vast varieties of microbes which comprise of decomposers, nitrogen fixing and denitrifying bacteria, methanogens, photosynthetic cyanobacteria, and chemolithoautotrohs etc. (Oertel et al., 2016). Decomposers play an important role in the regulation of global environmental temperature. The process of decomposition largely depends on the atmospheric temperature. As temperature increases and reach to its optimum value, bacteria become more active and perform the decomposition faster releasing more $\mathrm{CO}_{2}$ into the environment. It has been observed that targeting all GHGs simultaneously for mitigation would be more effective and advantageous than targeting $\mathrm{CO} 2$ alone (Weyant et al., 2006; Aldy et al., 2010). Biological nitrogen fixation (BNF) is an important phenomenon discovered by Beijerinck in 1901, through which molecular nitrogen present in the air is converted into nitrogenous compounds like ammonia $\left(\mathrm{NH}_{3}\right)$ in the soil by a group of microorganisms called nitrogen fixing bacteria. These bacteria may be free living or found in association with certain plants like leguminous plants in a symbiotic manner (Kumar and Rao, 2012). Another group of soil microbes called denitrifying bacteria convert a potential GHG, nitrous oxide into nitrogen gas which is harmless. It has been found that this ability is also present in other microorganisms which can be utilized to mitigate the emission of $\mathrm{N}_{2} \mathrm{O}$ in the atmosphere. Cyanobacteria are photosynthetic bacteria which play a vital role to reduce the GHG emission mainly from the oceans. Prochlorococcus and Synechococcus are abundantly found single cell cyanobacteria in marine ecosystem and are reported to remove about 10 billion tons of carbon from the air each year which is about two-third of the total carbon fixation that occurs in the oceans (Willey et al., 2009; Gupta et al., 2014). So an important fact emerged through this finding is that, the inherent or natural capabilities of these microorganisms can be effectively harnessed through the use of biotechnological methods for the reduction of GHGs. 
Methylacidiphilum infernorum, an extremely acidophilic methanotrophic aerobic bacteria first isolated and described in 2007, act as a biofilter to reduce methane emissions to atmosphere, and therefore serve as a potential target in strategies to combat global climate change (Dunfield et al., 2007). The bacteria belongs to Verrucomicrobia phylum and was first isolated from Hell's Gate (Tikitere), a methane-emitting geothermal field in the North of New Zealand and known to have a diverse habitat ranging from many terrestrial and aquatic habitats. The complete genome of Methylacidiphilum infernorum has been sequenced which can give some useful insights about its role in methane mitigation (Hou et al., 2008). Methylobacillus is another genus of anaerobic bacteria found largely in marine and fresh water ecosystems and act as one of the most important carbon recycler as they recycle carbon compounds as methane, methanol and methylated amines (Hanson \& Hanson, 1996). A major group of photosynthetic microorganisms generally referred as aerobic anoxygenic phototrophic bacteria (AAPB) found mainly in aquatic ecosystem and act as sink for $\mathrm{CO}_{2}$ sequestered from the atmosphere (Li et al., 2017; Jiao et al., 2003). Biomineralization is the widespread natural process of chemical alteration by microbes results in the precipitation of several minerals (Anbu et al., 2016). This process serves as an effective mean of $\mathrm{CO}_{2}$ sequestration. Microbially induced calcite precipitation (MICP) is an example of biomineralization which causes the removal of $\mathrm{CO}_{2}$ from environment by converting $\mathrm{CO}_{2}$ into carbonate minerals that can form different crystals such as calcite, aragonite, dolomite and magnesite using microbes (Ferris et al., 1994; Mitchell et al., 2010). It has been seen that, cement and concrete industry is responsible for $5 \%$ of the total industrial energy consumption and $5 \%$ of anthropogenic $\mathrm{CO}_{2}$ emissions (Worrel et $a l ., 2001)$. Therefore, the natural properties of biomineralizing microbes can be effective utilized in Bioconcrete and Biocement formation which is energy efficient and ecofriendly way of cement formation (De Muynck et al., 2010; Anbu et al., 2016). It has been proposed by many scientists that use of Carbonic anhydrase enzyme to reduce atmospheric $\mathrm{CO}_{2}$ can be an alternate method of biological sequestration of $\mathrm{CO}_{2}$ (Ramanan et al., 2009; Dhami et al., 2014). Carbonic anhydrase is a zinc containing metalloenzyme which is ubiquitous in prokaryotes and eukaryotes and involved in numerous physiochemical processes like photosynthesis, respiration, $\mathrm{CO}_{2}$ and ion transport and maintenance of acid base balance.

\section{Biofuel production and $\mathrm{CO}_{2}$ utilization}

The increase in global population demands more energy supply for improving the life quality. Among the energy sources, fossil fuels are used as a major energy source for past many years (Razzak et al., 2013). The consumption of fossil fuel is a potential cause of climate change as its combustion leads to massive emission of $\mathrm{CO}_{2}$. Due to this reason, the research encompassing the generation of ecofriendly alternative to fossil fuels has gained the importance from last some years and Biofuel is on the forefront among these. The use of biofuels can reduce fossil fuel consumption and hence reduce the emission of $\mathrm{CO}_{2}$ into atmosphere. The $\mathrm{CO}_{2}$ emitted through Biofuel burning are easily utilized by plants from atmosphere by the process of photosynthesis which makes biofuels carbon neutral (Demirbas, 2009). Biodiesel, bioethanol, biobutanol and biohydrogen are some of the examples of biofuels. Several approaches of biofuel production utilizing microbes have been well recognized and well established (Zhu, 2019). Biofuels are broadly classified into two categories: Primary and secondary biofuels (Rodionova et al., 2017). Primary biofuels comprise of unprocessed 
biofuel plant woods used for cooking. The secondary biofuels are processed liquid fuels produced from plant biomass utilizing algae and microbes. Plant biomass is considered as one of the best raw material for the production of biodiesel, bioalcohol and fermentation driven biohydrogen. The secondary biofuels are further categorized as first, second and third generation biofuels (Dragone et al., 2010; Rodionova et al., 2017). First generation biofuels comprise of the production of bioethanol or butanol and biodiesel from conventional starch and sugar rich plants like corn, barley, wheat, sugarcane and potato etc. The secondary biofuels are produced from novel starch, oil and sugar crops such as Jatropha, cassava or Miscanthus. The tertiary biofuels are produced by microalgae or seaweeds (Heiman, 2016). The genetic engineering tools utilizing E. coli and Bacillus subtilis can be employed to produce bioalcohol, isoprenoids and fatty acids derivatives in higher amounts (Dragone et al., 2010). Clostridium acetobutylicum and Clostridium beijerinckii has been reported to utilize acetone-butanol-ethanol fermentation for the production of biofuels (Gronenberg et al., 2013). Molecular hydrogen is one of the most promising sources of renewable energy produced by photosynthetic microbes including green alga (Martinez-Perez et al., 2007). Some bacteria are capable of producing molecular hydrogen anaerobically using carbohydrate rich biomass without light by the process known as dark fermentation (Hay et al., 2013).

\section{Nanotechnological approaches utilizing bacteria}

Nanotechnology has emerged as one of the most fascinating research areas over the last some years and can be utilized to address a variety of issues including utilization of atmospheric GHGs to reduce its effect on global climate change (Stander and Theodore, 2011; Khan et al., 2012). Nanotechnology basically deals with the manipulation of matter at nanoscale i.e. the dimensions of sizes in the range of one-billionth of a meter to generate useful products. Nanotechnology can enable the development of nanodevices which perform artificial photosynthesis where biocatalysts are used along with the semiconductor based light absorbers. This device can effectively mimic the natural process of photosynthesis. Few bacterial species have also been reported to be used as biocatalytic agents like Sporomusa ovata and genetically engineered E.coli (Liu et al., 2015). The development of nanowirebacteria hybrids is a novel technology which possesses a high reaction rate of $\mathrm{CO}_{2}$ reduction and can be effectively utilized for unassisted solar $\mathrm{CO}_{2}$ fixation to value-added chemicals (Liu et al., 2015). As discussed earlier, ubiquitously present Carbonic anhydrase enzyme can play an important role in atmospheric $\mathrm{CO}_{2}$ utilization. Single enzyme nanoparticle (SEN) based biosensor utilizing carbonic anhydrase has also been reported for gaseous $\mathrm{CO}_{2}$ sequestration (Yadav et al., 2011).

\section{Carbon eating bacteria: A novel discovery}

With the advent of genetic engineering and synthetic biology techniques, it is no more a big challenge to attain the targeted transformations in the natural biochemical pathways of microbes. A recent research claims the conversion of obligate heterotroph to full autotrophy over laboratory timescales, where a group of researchers from Israel have developed a carbon eating E.coli. The bacterium is engineered in such a way that it can generate biomass carbon from $\mathrm{CO}_{2}$ by utilizing a non native Calvin cycle (Gleizer et al., 2019). Generally autotrophs dominate over the heterotrophs on the earth in terms of utilization and sequestration of atmospheric 
$\mathrm{CO}_{2}$ and supply of biomass (Bar-On et al., 2018). The better understanding of their metabolic pathways enables scientists to construct the synthetic autotrophic E.coli with modified metabolic pathways (Smith and Stitt, 2007; Ort et al., 2015). Under the normal circumstances E.coli produces formate hydrogenlyase (FHL) enzyme which oxidizes formic acid to carbon dioxide and couples that reaction directly to the reduction of protons to molecular hydrogen (McDowall et al., 2014). The researchers unlocked the reverse reaction of FHL where pressurized $\mathrm{CO}_{2}$ and $\mathrm{H}_{2}$ allow FHL to function as a hydrogen dependent $\mathrm{CO}_{2}$ reductase and generate formate which accumulates outside the cell (Roger et al., 2018). The reducing power generated from this single carbon molecule formate (HCOO-) can be used for carbon fixation using Calvincycle for harvesting energy (Gleizer et al., 2019). The target has been achieved by employing different strategies which includes the incorporation of mutations in genes encoding for various enzymes to modify the metabolic pathways. The Chemostat cell culture based directed evolution led to complete trophic mode change in around 200 days (Gleizer et al., 2019). Undoubtedly, this study will provide a new and effective way of reducing atmospheric $\mathrm{CO}_{2}$ and serve as a stepping stone to future efforts for seeking new solutions toward the problem of global climate change.

Conclusion of the study is as follows:

It is quite clear that bacteria can be utilized in multiple ways to address the problem of global climate change by reducing emission and utilization of atmospheric GHGs. Looking toward the extend of the problem it is necessary to explore more than one option by utilizing the advanced technologies with special reference to microorganisms. There are several bacterial species which are still uncharacterized and can be used for the mitigation of GHGs. Advances in nanotechnology, genetic engineering, genomics, bioinformatics, synthetic biology and artificial intelligence can be explored for the context of global climate change.

\section{References}

Abatenh, E., Gizaw, B., Tsegaye, Z and Wassie, M. 2017. The Role of Microorganisms in Bioremediation- A Review. Open Journal of Environmental Biology. 2 (1): 38-46.

Aldy, J. E., Krupnick, A. J., Newell, R. G., Parry, I. W. H. and Pizer, W. A. 2010. Designing climate mitigation policy. J. Econ. Lit. 48: 903-34.

Al-Ghussain, L. 2018. Global Warming: Review on Driving Forces and Mitigation. Environmental Progress \& Sustainable Energy. 38(1):13-21.

Anbu, P., Kang, C. H., Shin, Y. J., and So, J. S. 2016. Formations of calcium carbonate minerals by bacteria and its multiple applications. SpringerPlus. 5:250. https://doi.org/10.1186/s40064-016-1869-2

Anderson, T. R., Hawkins, E. and Jones, P. D. 2016. $\mathrm{CO}_{2}$, the greenhouse effect and global warming: from the pioneering work of Arrhenius and Callendar to today's Earth System Models. Endeavour. 40: 178-187.

Bar-On, Y. M., Phillips, R., and Milo, R. 2018. The biomass distribution on Earth. Proc. Natl. Acad. Sci. USA. 115: 6506-6511.

Berg, J. M., Tymoczko, J. L. and Stryer, L. 2002. In Biochemistry. 5th edition. New York: W H Freeman; Section 20.1, The Calvin Cycle Synthesizes Hexoses from Carbon Dioxide and Water. Available from: https://www.ncbi.nlm.nih.gov/books/NBK2 2344

Chaturvedi, V., Eom, J., Clarke, L. E. and Shukla, P. R. 2014. Long term building energy demand for India: disaggregating end use energy services in an integrated assessment modeling framework. Energy Policy. 64:226-242.

De Muynck, W., De Belie, N. and Verstraete, W. 2010. Microbial carbonate precipitation in construction materials: a review. Ecol. Eng. $36: 118-136$ 
Demirbas, A. 2009. Political, economic and environmental impacts of biofuels: a review. Appl. Energy. 86:S108-117

Dhami, N. K., Reddy, M. S. and Mukherjee, A. 2014. Synergistic role of bacterial urease and carbonic anhydrase in carbonate mineralization. Appl.

Biochem.

Biotechnol. 172:2552-2561.

DOI: 10.1007/s12010-013-0694-0.

Dragone, G., Fernande, B., Vicente, A. A. and Teixeira, J. A. 2010. Third generation biofuels from microalgae. In: Mendez-Vilas A, editor. Current research, technology and education topics in applied microbiology and microbial biotechnology. Formatex: Pp. 1355-1366.

Dunfield, P., Yuryev, A., Senin, P., Smirnova, A. V., Stott, M. B., Hou, S., Ly, B., Saw, J. H., Zhou, Z., Ren, Y., Wang, J., Mountain, B. W., Crowe, M. A., Weatherby, T. M., Bodelier, P. L. E., Liesack, W., Feng, L., Wang, L. and Alam, M. 2007. Methane oxidation by an extremely acidophilic bacterium of the phylum Verrucomicrobia. Nature. $\quad 450(7171): \quad 879-882$. https://doi.org/10.1038/nature06411.

EPA-United States Environmental Protection Agency. 2017. Overview of Greenhouse Gases. Accessed on 15.04.2020.URL: https://www.epa.gov/ghgemissions/overvie w-greenhouse-gases.

Faseleh, J., M., Liang, J. B., Ho, Y. W., Mohamad, R., Goh, Y. M., Shokryazdan, P., and Chin, J. 2013. Lovastatin in Aspergillus terreus: fermented rice straw extracts interferes with methane production and gene expression in Methanobrevibacter smithii. BioMed research international. 604721. https://doi.org/10.1155/2013/604721

Ferris, F. G., Wiese, R. G. and Fyfe, W. S. 1994. Precipitation of carbonate minerals by microorganisms: implications for silicate weathering and the global carbon dioxide budget. Geomicrobiol. J. 12:1-13.

Gleizer, S., Ben-Nissan, R., Bar-On, Y. M., Antonovsky, N., Noor, E., Zohar, Y., Jona, G., Krieger, E., Shamshoum, M., Bar-Even, A., and Milo, R. 2019. Conversion of Escherichia coli to Generate All Biomass Carbon from CO2. Cell. 179(6): 1255- 1263.e12.

https://doi.org/10.1016/j.cell.2019.11.009

Gronenberg, L. S., Marcheschi, R. J. and Liao, J.

C. 2013. Next generation biofuel engineering in prokaryotes. Curr. Opin. Chem. Biol.17: 462-471.

Gupta, C. Prakash, D. and Gupta, S. 2014. Role of microbes in combating global warming. International Journal of Pharmaceutical Sciences Letters. 4 (2):359-363.

Hanson, R. S. and Hanson, T. E. 1996. Methanotrophic bacteria. Microbiological Reviews. 60(2): 439-471.

Hay, J. X. W., Wu, T. Y., Juan, J. C. and Jahim, J. M. 2013. Biohydrogen production through photo fermentation or dark fermentation using waste as a substrate: Overview, economics, and future prospects of hydrogen usage. Biofuels Bioprod. Biorefin. 7:334-352.

Heiman K. 2016. Novel approaches to microalgal and cyanobacterial cultivation for bioenergy and biofuel production. Curr. Opin. Biotechnol.38: 183-189.

Hou, S., Makarova, K. S., Saw, J. H., Senin, P., Ly, B. V., Zhou, Z., Ren, Y., Wang, J., Galperin, M., Omelchenko, M. V., Wolf, Y. I., Yutin, N., Koonin, E. V., Stott, M. B., Mountain, B. W., Crowe, M. A., Smirnova, A. V., Dunfield, P. F., Feng, L., Wang, L. and Alam, M. 2008. Complete genome sequence of the extremely acidophilic methanotroph isolate V4, Methylacidiphilum infernorum, a representative of the bacterial phylum Verrucomicrobia. Biol. Direct. 3:26. Published 2008 Jul 1. doi:10.1186/17456150-3-26

Hunt, K. A., Jennings, R. M., Inskeep, W. P. and Carlson, R. P. 2018. Multiscale analysis of autotroph-heterotroph interactions in a high-temperature microbial community. PLoS computational biology. 14(9): e1006431. https://doi.org/10.1371/journal.pcbi.100643 1

Janssen, P. H. and Kirs, M. 2008. Structure of the archaeal community of the rumen. Appl. Environ. Microbiol. 74:3619-3625.

Jiao, N., Sieracki, M. E., Zhang, Y. and Du, H. 2003. Aerobic anoxygenic phototrophic 
bacteria and their roles in marine ecosystems. Chin. Sci. Bull. 48: 1064-1068. https://doi.org/10.1007/BF03185754

Johnson, K. A. and Johnson, D. E. 1995. Methane emissions from cattle. Journal of Animal Science. 73: 2483-2492.

Khan, W. S., Ceylan, M., Asmatulu, E. and Asmatulu, R. 2012. Effects of nanotechnology on global warming. Proceedings of the 2012 Midwest Section Conference of the American Society for Engineering Education.

Knapp, J. R., Laur, G. L., Vadas, P. A., Weiss, W. P. and Tricarico, J. M. 2014. Invited review: Enteric methane in dairy cattle production: Quantifying the opportunities and impact of reducing emissions. J. Dairy Sci. 97:3231-3261.

Kumar, S. and Rao, B. 2012. Biological Nitrogen Fixation: A review. International Journal of Advanced Life Sciences. 1:1-9.

Kumar, S., Himanshu, S. K. and Gupta, K. K. 2012. Effect of Global Warming on Mankind - A Review. International Research Journal of Environment Sciences. 1(4):56-59.

Lamers, L. P., van Diggelen, J. M., Op den Camp, H. J., Visser, E. J., Lucassen, E. C., Vile, M. A., Jetten, M. S., Smolders, A. J., \& Roelofs, J. G. 2012. Microbial transformations of nitrogen, sulfur, and iron dictate vegetation composition in wetlands: a review. Frontiers in microbiology. 3:156. https://doi.org/10.3389/fmicb.2012.00156

Li, Q., Song, A., Wenjie, P., Jin, Z., Müller, W. E. G., Wang, X. 2017. Contribution of aerobic anoxygenic phototrophic bacteria to total organic carbon pool in aquatic system of subtropical karst catchments, Southwest China: evidence from hydrochemical and microbiological study, FEMS Microbiology Ecology. 93(6):fix065. https://doi.org/10.1093/femsec/fix065

Liu, C., Gallagher, J. J., Sakimoto, K. K., Nichols, E. M., Chang, C. J., Chang, M. C. Y. and Yang, P. 2015. Nanowire-Bacteria Hybrids for Unassisted Solar Carbon Dioxide Fixation to Value-Added Chemicals. Nano Lett. 15: 3634-3639. DOI: 10.1021/acs.nanolett.5b01254

Martin, C., Morgavi, D. P. and Doreau, M. 2010.
Methane mitigation in ruminants: from microbe to the farm scale. Animal. 4(3):351-365.

Martinez-Perez, N., Cherryman, S. J., Premier, G. C., Dinsdale, R. M., Hawkes, D. L., Hawkes, F. R. et al., 2007. The potential for hydrogenenriched biogas production from crop: scenarios in the UK. Biomass Bioenergy.31:95-104.

McDowall, J. S., Murphy, B. J., Haumann, M., Palmer, T., Armstrong, F. A., and Sargent, F. 2014. Bacterial formate hydrogenlyase complex. Proceedings of the National Academy of Sciences of the United States of America. 111(38): E3948-E3956. https://doi.org/10.1073/pnas.1407927111.

Mitchell, A. C., Dideriksen, K., Spangler, L. H., Cunningham, A. B. and Gerlach, R. 2010. Microbially enhanced carbon capture and storage by mineral- trapping and solubility- trapping. Environ. Sci. Technol. 44:5270-5276.

Morgavi, D. P., Jouany, J. P. and Martin, C. 2008. Changes in methane emission and rumen fermentation parameters induced by refaunation in sheep. Australian Journal of Experimental Agriculture. 48: 69-72.

National Oceanic and Atmospheric Administration (NOAA). 2019. Global climate report-2019. Accessed on 15.04.2020.

URL: https://www.ncdc.noaa.gov/sotc/global/201 913

Nejat, P., Jomehzadeh, F., Taheri, M. M., Gohari, M., Majid, M. Z. A. 2015. A global review of energy consumption, $\mathrm{CO}_{2}$ emissions and policy in the residential sector (with an overview of the top ten $\mathrm{CO}_{2}$ emitting countries). Renewable and Sustainable Energy Reviews. 43: 843-862.

Oertel, C., Matschullat, J. Zurba, K., Zimmermann, F. and Erasmi, S. 2016. Greenhouse gas emissions from soils-A review. Geochemistry. 76(3):327-352.

Oren, A. 2010. Microbial Metabolism: Importance for Environmental Biotechnology. Environmental Biotechnology. In: Wang L., Ivanov V., Tay JH. (eds) Environmental Biotechnology. Handbook of Environmental Engineering. 10: 193-255.

Ort, D. R., Merchant, S. S., Alric, J., Barkan, A., 
Blankenship, R. E., Bock, R., Croce, R., Hanson, M. R., Hibberd, J. M., Long, S. P., et al.,2015. Redesigning photosynthesis to sustainably meet global food and bioenergy demand. Proc. Natl. Acad. Sci. USA. 112: $8529-8536$.

Pandey, A. K., Das, N., Muthukumar, A. and Rao, S. 2015. Methanogens in the environment: an insight of methane yield and impact on global climate change. International Letters of Natural Sciences. 37:51-60.

Patra, A., Park, T., Kim, M. and Yu, Z. 2017. Rumen methanogens and mitigation of methane emission by anti-methanogenic compounds and substances. Journal of Animal Science and Biotechnology. 8:13. DOI 10.1186/s40104-017-0145-9.

Ramanan, R., Kannan, K., Sivanesan, S. D., Mudliar, S., Kaur, S., Tripathi, A. K. and Chakrabarti, T. 2009. Bio-sequestration of carbon dioxide using carbonic anhydrase enzyme purified from Citrobacter freundii. World J. Micribiol. Biotechnol. 25:981-987.

Razzak, S. A., Hossain, M. M., Lucky, R. A., Bassi, A. S. and de Lasa, H. 2013. Integrated $\mathrm{CO}_{2}$ capture, waste water treatment and biofuel production by microalgae culturing-a review. Renew. Sustain. Energy Rev. 27:622-653.

Rodionova, M. V., Poudyal, R. S., Tiwari, I., Voloshin, R. A., Zharmukhamedov, S. K., Nam, H. G., Zayadan, B. K., Bruce, B. D., Hou, H. J. M. and Allakhverdiev, S. I. 2017. Biofuel production: Challenges and opportunities. International Journal of Hydrogen Energy. 42(12): 8450-8461.

Roger, M., Brown, F., Gabrielli, W., and Sargent, F. 2018. Efficient Hydrogen-Dependent
Carbon Dioxide Reduction by Escherichia coli. Current biology. 28(1): 140-145.e2. https://doi.org/10.1016/j.cub.2017.11.050.

Smith, A. M., and Stitt, M. 2007. Coordination of carbon supply and plant growth. Plant Cell Environ. 30: 1126-1149.

Stander, L. and Theodore, L. 2011. Environmental Implications of Nanotechnology-An Update. Int. J. Environ. Res. Public Health. 8:470-479.

Venkataramanan, S. 2011. Causes and effects of global warming. Indian Journal of Science and Technology. 4: 226-229.

Weyant, J. P., De la Chesnaye, F. and Blanford, G. 2006. Overview of EMF-21: Multigas mitigation and Climate Policy. The Energy Journal. Special issue-3: 1-32. DOI: $10.2307 / 23297073$.

Willey, J. M., Sherwood, L. M. and Woolverton, C. J. 2009 Prescott's Principles of Microbiology, McGraw-Hill, New York.

Worrel, E., Price, L., Hendricks, C. and Meida, L. O. 2001. Carbon dioxide emission from the global cement industry. Annu. Rev. Energy Environ. 26:303-329.

Wright, A. D., Kennedy, P., O'Neill, C. J., Toovey, A. F., Popovski, S., Rea, S. M., Pimm, C. L. and Klein, L. 2004. Reducing methane emissions in sheep by immunization against rumen methanogens. Vaccine. 22: 3976-3985.

Yadav, R., Labhsetwar, N., Kotwal, S. and Rayalu, S. 2011. J. Nanopart. Res. 13:263271. DOI 10.1007/s11051-010-0026-z.

Zhu, Q. 2019. Developments on CO2-utilization technologies. Clean Energy. 3(2):85-100.

\section{How to cite this article:}

Shaurya Dumka, Chinmay Gupta and Aman Kamboj. 2020. Utilizing Bacteria to Mitigate Global Climate Change: A Review. Int.J.Curr.Microbiol.App.Sci. 9(05): 1385-1394. doi: https://doi.org/10.20546/ijcmas.2020.905.157 